\title{
The intracellular localization of malate dehydrogenase isoenzymes in Pisum arvense roots
}

\author{
GENOWEFA KUBIK-DOBOSZ \\ Department of Plant Physiology, Institute of Botany, Wroclaw University, Kanonia 6/8, \\ 50-328 Wrocław, Poland \\ (Received December 9.1985. Accepted January 22. 1986)
}

\begin{abstract}
Mitochondria and plastids were isolated from Pisum arvense root cells by sucrose density gradient centrifugation. The individual subcellular fractions so obtained were subiected to isoclectric focusing on cellulose acetate strips Mitochondria and plastids each contained one NAD -malate dehydrogenase, while three isoenzymes were associated with the supernatant.
\end{abstract}

Key words: Pisum arvense, malate dehydroqenase isoenzymes

\section{INTRODUCTION}

Malate dehydrogenase (MDH E.C. 1.1.1.37) has been demonstrated in the cytosol, mitochondria, chloroplasts, glyoxisomes and peroxisomes of photosynthetic tissues (Hock 1973a, Nainawatee et al. 1974, Walk and Hock 1977, Gietl and Hock 1982). Only two or three moleculat forms of MDH have been found in the cytosol and mitochondria of root cells of several plant species (Ting et al. 1966, Rocha and Ting 1970, Zschoche and Ting 1973, Mazurowa and Ratajczak 1980). Other molecular forms of the enzyme in the remaining structures of root tissues have not been reported.

Our earlier studies have enabled the separation of plastids from the remaining $P$. arvense root-cell organelles (Kubik-Dobosz and Kłobus 1985). At the same time it was found that the plastids contained a NADH-MDH which took part in transferring reducing equivalents from the cytosol to the interior of root plastids (Kubik-Dobosz 1986). In 
order to establish the intracellular localization of the various molecular forms of $\mathrm{MDH}$ in $P$. arvense roots, the enzymatic proteins contained in the cytosol, mitochondria and plastids were subjected to isoelectric focusing on cellulose acetate strips.

\section{MATERIAL AND METHODS}

Pisum arvense L. (var. 'Nieznaniecka') seedlings were grown for 7 days in Hoagland's medium ( $\mathrm{pH}$ 6.5) under the conditions given in Kłobus et al. (1983). $P$. arvense roots were ground with $0.05 \mathrm{M}$ Hepes- $\mathrm{NaOH}$ (pH 7.5) buffer containing $10 \mathrm{mM} \mathrm{KCl}, 2 \mathrm{mM} \mathrm{MgCl}_{2}, 5 \mathrm{mM}$ EDTA, $10 \mathrm{mM}$ dithiothreitol, $0.4 \mathrm{M}$ sucrose and $1^{\circ}$, bovine serum albumin, using $20 \mathrm{~cm}^{3}$ of the extraction solution per $20 \mathrm{~g}$ of tissue. The homogenate was filtered through a double layer of Miracloth and layered on a discontinuous sucrose density gradient made from $60^{\circ}{ }_{\circ}, 50^{\circ}{ }_{\circ}$ and $30^{\circ}$ (w/w) sucrose (Kubik-Dobosz and Kłobus 1985). The samples were centrifuged for $5 \mathrm{~min}$. at $2900 \times \mathrm{g}$ and then for $30 \mathrm{~min}$. at $18000 \times \mathrm{g}$. The plastid and mitochondria fractions were diluted two-fold with $0.05 \mathrm{M}$ Hepes- $\mathrm{NaOH}$ buffer ( $\mathrm{pH}$ 7.5) containing $3 \mathrm{mM}$ EDTA and centrifuged for $15 \mathrm{~min}$. at $12000 \times \mathrm{g}$. The plastid and mitochondria pellets were suspended in $2 \mathrm{~cm}^{3} 0.05 \mathrm{M}$ Hepes- $\mathrm{NaOH}$ ( $\mathrm{pH}$ 7.0) buffer containing $0.2 \mathrm{M}$ sucrose and $0.3 \mathrm{M}$ mannitol. The purity of the plastid and mitochondria fractions was tested with the aid of marker enzymes.

The activities of the marker enzymes and MDH were assayed in the plastid and mitochondria fractions and in the supernatant after adding Triton X-100 to a final concentration of $0.5^{\circ}{ }_{0}$. Glucose-6-phosphate dehydrogenase was assayed according to the method of Devlin and Galloway (1968), cytochrome c oxidase by the method of Smith (1955) and catalase by the method of Luck (1965). The method of Spalding and Edwards (1978) was used to determine the activity of phosphoenolopyruvate carboxylase and the method of Wakiuchi et al. (1971) for malate dehydrogenase. A unit of enzyme activity was taken to equal $1 \mu \mathrm{mol}$ of product or substrate per min. per $1 \mathrm{~cm}^{3}$ of the fraction.

Isoelectric focusing of the enzymic proteins was done on Cellogel. Strips of cellulose acetate were methylated in a $5 \%$ solution of boron fluoride in methanol according to the method of Dobosz and Koziof (1980), and then soaked for $30 \mathrm{~min}$. in a solution containing $0.25 \mathrm{~cm}^{3}$ Ampholine 4-6, $0.25 \mathrm{~cm}^{3}$ Servalite $3-7,50 \mathrm{mg}$ polyvinylpyrrolidone and $4 \mathrm{~cm}^{3} \mathrm{H}_{2} \mathrm{O}$. Excess ampholyte was removed with tissue paper, next, samples $0.002 \mathrm{~cm}^{3}$ in volume were applied to the center of the strip. Before application, the supernatant and mitochondrial fractions were diluted 
6-fold with distilled water. The anode solution contained $0.1 \mathrm{M} \mathrm{H}_{3} \mathrm{PO}_{4}$ the cathode $-0.1 \mathrm{M} \mathrm{L}$-alanine. Isoelectric focusing was carried out for 60 min. at $500 \mathrm{~V}$, using a miyture of hemoglobin and cytochrome c as markers. Next, the samples were stained for malate dehydrogenase according to Harris and Hopkinson (1976). The strip was placed on a agarose gel containing $0.2 \mathrm{M}$ Tris- $\mathrm{HCl}(\mathrm{pH}$ 8.0), $50 \mathrm{mM}$ L-malate, $2 \mathrm{mg} \mathrm{NAD}{ }^{+}, 1.5 \mathrm{mg}$ phenazine methosulphate, $1 \mathrm{mg}$ 3-(4,5-dimethyl-thiazolyl-2)-2,5-diphenyl tetrazolium bromide and $1 \%$ agarose in a final volume of $10 \mathrm{~cm}^{3}$.

The plastid suspension $\left(0.5 \mathrm{~cm}^{3}\right)$ was incubated for 30 or $60 \mathrm{~min}$. in Hepes- $\mathrm{NaOH}$ buffer ( $\mathrm{pH}$ 7.0), $0.2 \mathrm{M}$ sucrose, $0.3 \mathrm{M}$ mannitol, 0.3\%。 bovine serum albumin, $1.25 \mathrm{mM}$ ATP with or without $2.5 \mathrm{mM}$ malate in a final volume of $3 \mathrm{~cm}^{3}$. Next, the samples were deproteinized with $0.75 \mathrm{~cm}^{3} 2 \mathrm{M} \mathrm{HClO}_{4}$ and, after removing the protein sediment, neutralized with $1 \mathrm{M} \mathrm{K}_{2} \mathrm{CO}_{3}$. The potassium perchlorate precipitate was discarded and the level of oxaloacetate assayed in the supernatant (Hohorst and Reim 1970) by measuring the rate of $\mathrm{NADH}_{2}$ oxidation in the presence of exogenous malate dehydrogenase.

\section{RESULTS}

The enzymatic analysis of the subcellular fractions of $P$. arvense roots showed that the supernatant, mitochondria and plastids contained malate dehydrogenase activity (Table 1 ). The $P$. arvense root plastid

\section{Table 1}

The activities of malate dehydrogenase and marker enzymes in subcellular fractions from Pisum arvense roots. The activities of all of the enzymes are expressed in miliunits

\begin{tabular}{|l|c|c|c|c|c|}
\hline \multicolumn{1}{|c|}{ Fraction } & $\begin{array}{c}\text { Malate } \\
\text { dehydro- } \\
\text { genase }\end{array}$ & $\begin{array}{c}\text { Cyto- } \\
\text { chrome c } \\
\text { oxidase }\end{array}$ & Catalase & $\begin{array}{c}\text { Glucose-6-phos- } \\
\text { phate } \\
\text { dehydrogenase }\end{array}$ & $\begin{array}{c}\text { Phosphoenol- } \\
\text {-pyruvate } \\
\text { carboxylase }\end{array}$ \\
\hline Supernatant & 4437 & 7.1 & 39.7 & 188.1 & 104.2 \\
Mitochondria & 3858 & 26.8 & 34.4 & 4.5 & 0 \\
Plastids & 235 & 0 & 0 & 16.1 & 0 \\
\hline
\end{tabular}

fraction obtained in a sucrose density gradient, did not exhibit cytochrome c oxidase and catalase activites, characteristic for mitochondria or microbodies (Table 1). The individual organelle fractions were also not contaminated by the cytosol fraction, as indicated by the lack of phosphoenolopyruvate carboxylase activity in them.

The supernatant and fractions corresponding to mitochondria and 
Table 2

The effect of malate on the releasing of oxaloacetate (nmoles) into the incubation medium containing plastids isolated from Pisum arvense roots

\begin{tabular}{|c|c|c|}
\hline Medium & \multicolumn{2}{|c|}{ Oxaloacetate } \\
\hline \multirow{3}{*}{$\begin{array}{c}\text { Plastids + ATP }(1.25 \mathrm{mM})+ \\
\text { malate }(2.5 \mathrm{mM})\end{array}$} & $30 \mathrm{~min}$ & $60 \mathrm{~min}$ \\
\cline { 2 - 3 } Plastids + ATP $(1.25 \mathrm{mM})$ & $12.1 \pm 1.4$ & $28.6 \pm 2.1$ \\
\hline
\end{tabular}

plastids were subjected to isoelectric focusing on cellulose acetate strips. In the $\mathrm{pH}$ gradient of 3-7 formed between the electrodes, the malate dehydrogenase in the individual subcellular fractions separated into three groups of enzymatic proteins differing in their isoelectric points (Fig. 1).

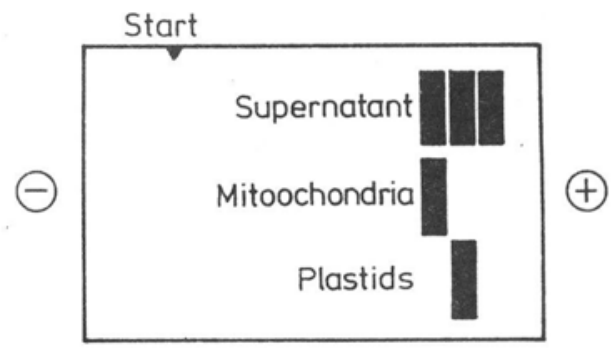

Fig. 1. Malate dehydrogenase isoenzymes in subcellular fractions from Pisum arvense roots

Three malate dehydrogenase isoenzymes were found in the supernatant. Mitochondria contained only one $\mathrm{MDH}$ isoenzyme. Also, in the plastids, only one MDH isoenzyme was found. which. however, differed from that in the mitochondria.

When the plastids isolated from $P$. arvense roots were incubated in a solution containing malate. oxaloacetate was found to accumulate in the incubation medium (Table 2).

\section{DISCUSSION}

Pisum arvense root cells exhibited a very high activity of cytoplasmic malate dehydrogenase, which is understandable when its physiological function in photosynthetic tissues is taken into account. From the report by Heber (1974) and House and Anderson (1980) it is seen that MDH takes part in the metabolism of malate in the cytoplasm and and participates in the transfer of reducing equivalents across chloroplast membranes. Three MDH isoenzymes were found in the supernatant fraction 
from $P$. artins roots. This fact may indicate that these different forms of $\mathrm{MDH}$ are present in the cytosol or that they are leaked there from different organelles during homogenization.

Through isoelectric focusing of enzymatic proteins from $P$. arvense roots, it was shown that the mitochondrial fraction contained only one $\mathrm{MDH}$ isoenzymes whose high activity allows it to be assigned to the enzymes involved in the tricarboxylic acid cycle (Price and Thimann 1954). Under the conditions of isolation of $P$. arvense root cell organelles, the presence of catalase activity was found in the mitochondrial fraction. In a previous paper (Kubik-Dobosz and K lobus 1985) it was suggested that it is possible that associations are formed between mitochondria and microbodies of $P$. arvense roots. The finding of only one $\mathrm{MDH}$ isoenzyme in the mitochondrial fraction and the lack of a specific isoenzyme in the remaining fractions exhibiting catalase activity proves that the $\mathrm{MDH}$ isoenzyme associated with the microbody fraction is not present in the studied tissues. These results, then, support the reports of other authors who did not find the microbody $\mathrm{MDH}$ isoenzyme in root tissues (Ting et al. 1966, Rocha and Ting 1979).

Hock (1973b) established the isoelectric points of various MDH isoenzymes in the cotyledons of Citrullus vulgaris and found that they fell in the range of $\mathrm{pH}$ 4.7-6.4 with the exception of the glyoxisome isoenzyme with an isoelectric point at $\mathrm{pH}$ 8.7. As shown in the isoelectric focusing of proteins from $P$. arvense roots in the full (unpublished data) and limited to $\mathrm{pH}$ 3-7 ranges, the $\mathrm{MDH}$ isoenzymes in the various cell compartments were acidic in nature with isoelectric points below 7.0.

Zschoche and Ting (1973) did not succeed in separating P. artense root plastids from other subcellular structures using the technique of sucrose density gradients. Our experiments have succeeded in isolating the plastid fractions from $P$. arvense roots (Kubik-Dobosz and Kłobus 1985). The purified plastids contained a specific $\mathrm{MDH}$ isoenzyme. In addition, the demonstration of the presence of oxaloacetate in the medium containing isolated plastids and malate additionally confirms the catalytic properties of the MDH localized in $P$. arvense root plastids. The results presented in the paper by Kubik-Dobosz (1986) suggest in addition that the physiological function of the plastid MDH isoenzyme may be its participation in the transport of reduced pyridine nucleotides from the cytoplasm to $P$. arvense root plastids. 


\section{REFERENCES}

Devlin R. M., Galloway R. A., 1968. Oxidative enzymes and pathways of hexose and triose metabolism in Chlorella. Physiol. Plant. 21: 11-25.

Dobosz T., Koziof P., 1980. Subtypes of the phosphoglucomutase-1 ( $\left.\mathrm{PGM}_{1}\right)$ locus detectable in polish population by isoelectric focusing on cellogel. Hum. Genet. 56: $119-121$.

Gietl C., Hock B., 1982. Organelle-bound malate dehydrogenase isoenzymes are synthesized as higher molecular weight precursors. Plant Physiol. 70: 483-487.

Harris H., Hopkinson D. A., 1976. The enzymes. In: Handbook of enzyme electrophoresis in human genetics. North-Holland Publishing Co., Amsterdam-Oxford-New York.

Heber U., 1974. Metabolite exchange between chloroplasts and cytoplasm. Ann. Rev. Plant Physiol. 25: 393-421.

Hock B., 1973a. Isoenzymes of malate dehydrogenase from watermelon seedlings: disappearance of microheterogenity during germination. Planta 110: 329-344.

Hock B., 1973b. Compartmentation and properties of the MDH-isoenzymes from watermelon cotyledons. Planta 112: 137-148.

Hohorst H.-J., Reim M., 1970. Oxalacetat. UV-Spektrophotometrische Bestimmung. In: Methoden der enzymatischen Analyse. H. U. Bergmeyer (ed.), Akademie-Verlag, Berlin. Bd. III, pp. $1560-1564$.

House C. M., Anderson J. W., 1980. Light dependent reduction of nitrate by pea chloroplasts on the presence of nitrate reductase and $\mathrm{C}_{4}$ dicarboxylic acid. Phytochemistry 19: 1925-1930.

Kłobus G., Kubik-Dobosz G., Buczek J., 1983. The intracellular location of nitrogen metabolism enzymes in Pisum arvense L. roots. Acta Soc. Bot. Pol. 52: 215-222.

Kubik-Dobosz G., 1986. The role of malate in the synthesis of glutamate in Pisum artense roots. Acta Soc. Bot. Pol. 55: 611-619.

Kubik-Dobosz G., Kłobus G., 1985. The localization of nitrite reductase, glutamate synthase and malate metabolism enzymes in Pisum arvense $\mathrm{L}$. roots. Acta Soc. Bot. Pol. 54: 85-93.

Luck H., 1965. Catalase. In: Methods of enzymatic analysis. H. U. Bergmeyer (ed.), Academic Press. New York, pp. 855-888.

Mazurowa H., Ratajczak W., 1980. Activation of some dehydrogenases in nodules and roots of Lupinus luteus L. Acta Physiol. Plant. 2: 299-306.

Nainawatee H. S., Mehta S. L., Das N. B., 1974. Soluble and chloroplast malate dehydrogenase isoenzymes of Triticum aestivum. Phytochemistry 13: 553-557.

Price C. A., Thimann K. V., 1954. The estimation of dehydrogenase in plant tissue. Plant Physiol. 29: 113-124.

Rocha V., Ting I. P., 1970. Tissue distribution of microbody, mitochondrial and soluble malate dehydrogenase isoenzymes. Plant Physiol. 46: 754-756.

Smith L., 1955. Methods in enzymology. Colowick S. P., Kaplan N. O. (eds), Vol. 2 , Academic Press, New York. pp. 740.

Spalding M. H., Edwards G. E., 1978. Photosynthesis in enzymatically isolated leaf cells from the CAM plant Sedum telephium L. Planta 141: 59-63.

Ting I. P., Sherman I. W., Dugger W. M. Jr., 1966. Intracellular location and possible function of malate dehydrogenase isoenzymes from young maize root tissue. Plant Physiol. 41: 1083-1084.

Wakiuchi N., Matsumoto H., Takahashi E., 1971. Changes of some enzyme activities of cucumber during ammonium toxicity. Physiol. Plant. 24: 248-253. 
Walh R-A. Hock B. 1977. Glyoxysomal and mitochondrial malate dehydrogenase of watermelon (Citrullus rulqaris) cotyledons. I Molecular properties of the purified isoenzymes. Planta 136: 211-220

Zschoche W. C. Ting I. P. 1973. Malate dehydrogenase of Pisum saticum Tissue distribution and properties of particulate forms. Plant Physiol 51: 1076-1081.

Wewnatrzkomórkowe rozmieszczenie izoenzymów dehydroqenazy jablczanej w korzeniach Pisum arvense $L$.

\section{Streszczenie}

Mitochondria i plastydy izolowano , homoreh horzeni Pisum artense za pomoca wirowania w gradiencie gestości sacharazy Poszczególne frahcje subhomórhowe poddano elektroogniskowaniu na folii / octanu celulosy Mitochondria i plastydy zawierały po jednym izoenzymic dehydrogenazy jabłczanowej zależnej od NAD natomiast trzy izoenzymy byly związanc 7 frakcją supernatantową 